\title{
Assessment of Groundwater Quality and Human Health Risk (HHR) Evaluation of Nitrate in the Central-Western Guanzhong Basin, China
}

\author{
Qiying Zhang ${ }^{1,2}$, Panpan $\mathrm{Xu}^{1,2}$ and Hui Qian ${ }^{1,2, *(1)}$ \\ 1 School of Environmental Science and Engineering, Chang'an University, Xi'an 710054, China; \\ zhangqiying@chd.edu.cn (Q.Z.); 2017029001@chd.edu.cn (P.X.) \\ 2 Key Laboratory of Subsurface Hydrology and Ecological Effects in Arid Region of the Ministry of Education, \\ Chang'an University, Xi'an 710054, China \\ * Correspondence: qianhui@chd.edu.cn
}

Received: 27 September 2019; Accepted: 29 October 2019; Published: 1 November 2019

\begin{abstract}
To investigate the quality of domestic groundwater and assess its risk to inhabitants of the Guanzhong Basin, China, 191 groundwater samples were collected to analyze major ions, nitrate, $\mathrm{pH}$, total dissolved solids (TDS), total hardness (TH), and electrical conductivity (EC). The physiochemical parameters, hydrochemical facies, and sources of major ions were analyzed using Durov diagrams, bivariate diagrams, and chloro-alkaline indices (CAI-I and CAI-II). The suitability of groundwater for drinking, the nitrate distribution, and human health risk (HHR) for different age groups were evaluated. The results showed that the relative abundance of cations in the groundwater samples was $\mathrm{K}^{+}+\mathrm{Na}^{+}>\mathrm{Ca}^{2+}>\mathrm{Mg}^{2+}$, while that of anions was $\mathrm{HCO}_{3}{ }^{-}>\mathrm{SO}_{4}{ }^{2-}>\mathrm{Cl}^{-}>\mathrm{NO}_{3}{ }^{-}$. Groundwater samples mainly contained $\mathrm{HCO}_{3}-\mathrm{Na}$ and $\mathrm{HCO}_{3}-\mathrm{Ca}$, which were introduced mainly by rock weathering and ion exchange. The groundwater in the Guanzhong Basin contained mainly good and medium water, and the groundwater in the southern part of the Wei River was better than that north of the Wei River. Areas containing high nitrate concentrations were mainly located in the central and western parts of the Guanzhong Basin. The percentages of low risk ( $<45 \mathrm{mg} / \mathrm{L})$, high risk $(45-100 \mathrm{mg} / \mathrm{L})$, and very high risk ( $>100 \mathrm{mg} / \mathrm{L})$ of nitrate pollution in the study area were $90.58 \%$, $8.9 \%$, and $0.52 \%$, respectively. The HHR assessment results indicated that people in the 6-12 month age group were more likely to suffer from health complications due to a higher nitrate concentration, followed by $6-11$ years, $21-65$ years, $18-21$ years, $\geq 65$ years, $11-16$ years, and $16-18$ years age groups, which was mainly due to the different exposure parameters. The results of this study will be useful in regional groundwater management and protection.
\end{abstract}

Keywords: groundwater quality; nitrate contamination; health risk assessment; water quality index; Guanzhong Basin

\section{Introduction}

Groundwater is extensively used for agricultural, industrial, and drinking purposes in many arid and semi-arid regions (e.g., Western United States, Algeria, Egypt, China, and Australia) where rainfall is infrequent and surface water is scarce [1-4]. Groundwater accounts for only $29.9 \%$ of all global freshwater resources [1,5], and water resource shortages have become one of the most important challenges to humankind $[4,6]$. Moreover, groundwater resources have drastically declined not only in quality but also in quantity due to untreated effluents from industrial and agricultural development, expanding urbanization, population growth, inadequate sanitation, and pollutant runoff in arid and semi-arid regions $[2,7,8]$. Hydrochemical characteristics are widely used to indicate the source 
of the main components of ions, types of groundwater, water-rock interactions, and groundwater reservoir environments [9]. Knowledge of hydrochemical characteristics is useful for evaluating groundwater quality because it provides an understanding of groundwater suitability for various purposes. Investigations have shown that exposure to potentially toxic chemicals, such as heavy metals, fluorides, and nitrate in groundwater can pose great risks to human health $[10,11]$.

Nitrate is one of the main groundwater pollutants and significantly impacts groundwater quality. Groundwater pollution can affect human health and is the most widespread source of health problems in arid and semi-arid regions around the world [12-14]. Excessive nitrate in drinking groundwater has been reported to cause various health complications, including abortions, blue baby syndrome, increased risk of methemoglobinemia and gastric cancer, damage to stomach lining, mouth ulceration, and reproductive damage [15-17]. Therefore, the concentration of nitrate in groundwater should be monitored. Adimalla et al. [12] evaluated the fluoride and nitrate pollution of groundwater in the semi-arid region of Nirmal Province, South India and found that high fluoride and nitrate concentrations in water caused health issues in humans. Adimalla and Li [18] suggested that high fluoride and nitrate concentrations in water in the semi-arid region, Telangana State, India posed a risk to residents and made water unsuitable for drinking. Wu et al. [17] studied severe nitrate pollution and health risks of a coastal aquifer, and the results showed that groundwater nitrate concentrations exerted non-carcinogenic health risks for different age groups. Nejatijahromi et al. [19] analyzed the stable isotope ratios $\left(\delta^{15} \mathrm{~N}_{-\mathrm{NO}_{3}}{ }^{-}, \delta^{18} \mathrm{O}-\mathrm{NO}_{3}{ }^{-}, \delta^{18} \mathrm{O}-\mathrm{H}_{2} \mathrm{O}\right.$, and $\left.\delta \mathrm{D}-\mathrm{H}_{2} \mathrm{O}\right)$ of groundwater samples and inferred that the main nitrate sources in groundwater were chemical fertilizers and treated wastewater near Tehran, Iran. Similar studies in other regions have also been carried out $[15,20,21]$.

The Guanzhong Basin is located on the "Silk Road Economic Belt" in a semi-arid area in Shaanxi Province, China, and has supported significant agriculture since the Qin Dynasty $[9,22]$. Moreover, this region is the political, economic, and cultural center of Shaanxi Province and has a significant influence on China's national regional economic pattern [23,24]. Sixty percent of the population, $80 \%$ of industry, and $52 \%$ of cultivated land in Shaanxi are located in the Guanzhong Basin. However, natural factors and human activities have caused many environmental problems, such as water resource shortages, which have exacerbated water pollution [25,26]. Large amounts of irrigation water and fertilizer are used each year in traditional farming areas, causing nitrate to pollute groundwater which is mainly used for human consumption. Polluted groundwater may cause great risks to human health $[13,27]$, making it important to study the current status of nitrate pollution and associated health risks in the Guanzhong Basin.

Therefore, the main objective of this study was to (1) study the hydrogeochemical characteristics, hydrochemical facies of groundwater, and their formation mechanisms; (2) appraise the overall groundwater quality for drinking purposes using the water quality index (WQI); (3) analyze the distribution and main sources of nitrate in the Guanzhong Basin; and (4) assess the non-carcinogenic health risks posed by drinking nitrate-contaminated groundwater for different age groups (6-12 months, 6-11 years, $11-16$ years, $16-18$ years, $18-21$ years, $21-65$ years, and $\geq 65$ years). The outcome of this study provides essential information for policy and decision makers to take appropriate action to improve the groundwater quality in the study region.

\section{Study Area}

The Guanzhong Basin covers an area of $2 \times 10^{4} \mathrm{~km}^{2}$ and is located at approximately $33^{\circ} 00^{\prime}-35^{\circ} 20^{\prime}$ $\mathrm{N}$ and $106^{\circ} 30^{\prime}-110^{\circ} 30^{\prime} \mathrm{E}$ in the middle of Shaanxi Province, China $[28,29]$. Its average elevation is about $400 \mathrm{~m}$ above sea level (a.s.l.) [28]. The Guanzhong Basin is also one of the largest basins of the Yellow River Catchment in China [30] and is located between the Qinling Mountains in the south with a maximum elevation of $3767 \mathrm{~m}$ a.s.l. and the North Mountains in the north with a maximum elevation of 1678 m a.s.l. [31], as shown in Figure 1a. The North Mountains are covered by quaternary loess and loess-like deposits, which are the main source of sediments in the rivers [26]. The population of the Guanzhong Basin includes the population of Xi'an (8.07 million), Weinan (5.47 million), 
Xianyang (4.98 million), and Baoji (3.76 million), accounting for about $60 \%$ of the total population (37.2 million) of Shaanxi Province. Moreover, the Guanzhong Basin is an important section of the Silk Road economic belt and has been part of the most important political, economic, cultural, social, and educational areas of the world $[9,32,33]$.

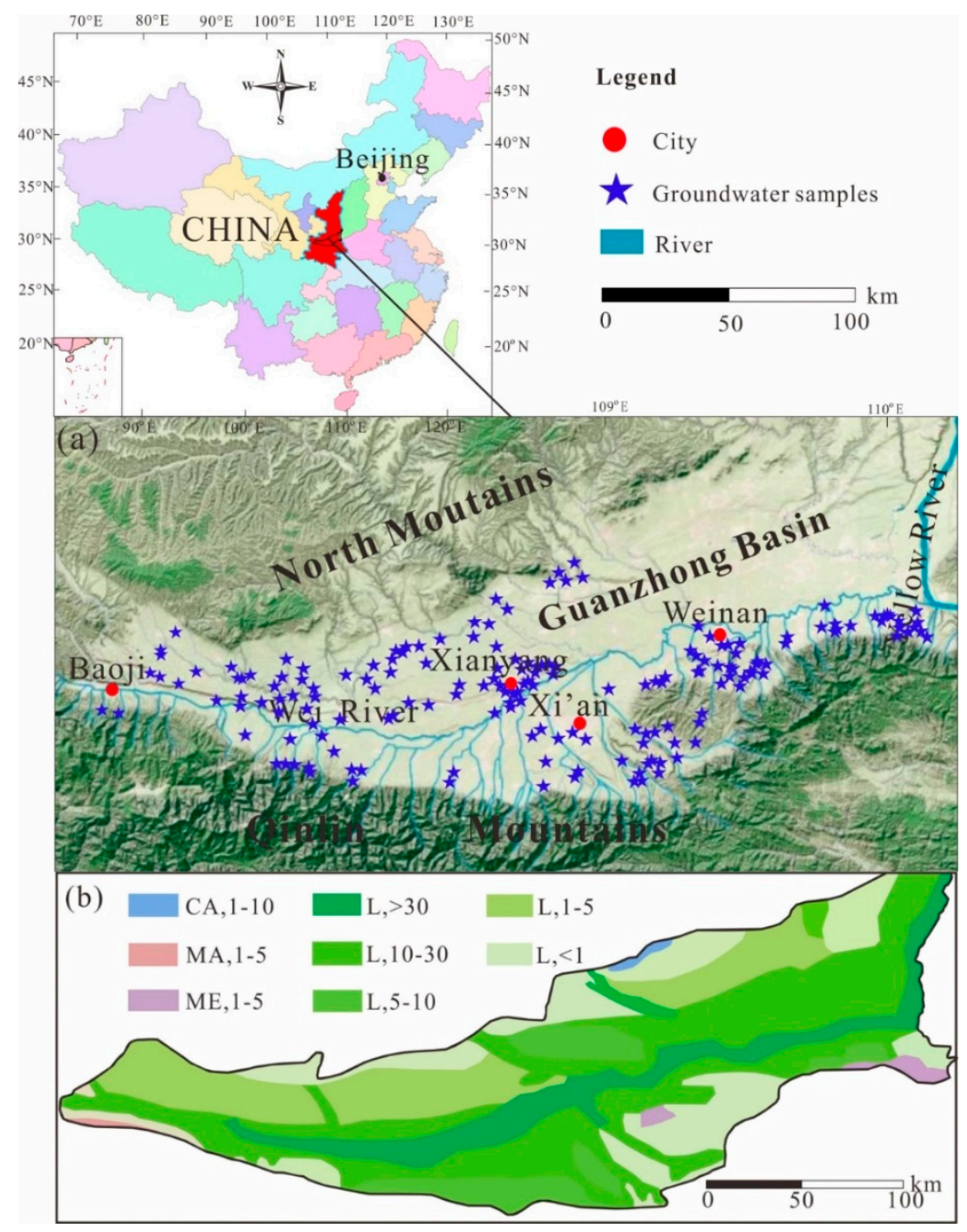

Figure 1. Study area showing (a) geographical locations of sampling sites and (b) the geological map. Fissure-karst water-bearing formations: CA, carbonate; MA, magmatic; ME, metamorphic; L, loose porous sediment. The number after the letter represents the mass specific storage $\left(\mathrm{t} / \mathrm{h}^{*} \mathrm{~m}\right)$.

This region is characterized by a temperate continental monsoon climate with an annual average rainfall of $573 \mathrm{~mm}$, approximately $78 \%$ of which occurs from May to October [9,26]. Evaporation generally ranges between 1000 and $1200 \mathrm{~mm}$ per year [34]. The annual average temperature is $13.3^{\circ} \mathrm{C}$, the average annual daylight is $1500-2200 \mathrm{~h}$, and the frost-free period is $200-220$ days. The Wei River, the largest tributary $(502.4 \mathrm{~km})$ of the Yellow River, receives 538 million $\mathrm{m}^{3}$ of the average annual runoff in Shaanxi Province [28].

The Guanzhong Basin is a Cenozoic fault basin, and subsidence in the basin began in the Late Eocene and continued throughout the Miocene and Pliocene epochs, leading to the deposition of a thick sequence of tertiary fluvial-lacustrine clastic rocks [34]. Therefore, the main water-bearing rock formation of the Guanzhong Basin is loose sediment-type pore water-bearing formation (L) formed in the quaternary, as shown in Figure 1b. The aquifers also include carbonate fissure-karst water-bearing rock formations (CA) in the North Mountains and magmatic fissure-karst water-bearing 
rock formations (MA) and metamorphic fissure water-bearing rock formations (ME) in the Qinling Mountains [26]. Groundwater can be recharged by surface water due to the loose sediment pore water-bearing formations, which have good permeability and high leakage coefficients.

\section{Materials and Methods}

\subsection{Sample Collection and Analysis}

In the study region, 191 groundwater samples were collected from a phreatic aquifer in the central-western Guanzhong Basin in 1999, as shown in Figure 1. All samples were analyzed for various hydrochemical parameters, such as $\mathrm{pH}$, total dissolved solids (TDS), electrical conductivity (EC), total hardness $\left(\mathrm{TH}\right.$, as $\left.\mathrm{CaCO}_{3}\right)$, potassium and sodium $\left(\mathrm{K}^{+}+\mathrm{Na}^{+}\right)$, calcium $\left(\mathrm{Ca}^{2+}\right)$, magnesium $\left(\mathrm{Mg}^{2+}\right)$, chloride $\left(\mathrm{Cl}^{-}\right)$, sulfate $\left(\mathrm{SO}_{4}^{2-}\right)$, bicarbonate $\left(\mathrm{HCO}_{3}{ }^{-}\right)$, and nitrate $\left(\mathrm{NO}_{3}{ }^{-}\right)$. $\mathrm{pH}$ and TDS were measured immediately in the field using portable devices, and EC was calculated from TDS. The TH, $\mathrm{Ca}^{2+}$, and $\mathrm{Mg}^{2+}$ were analyzed by a titrimetric method using EDTA. $\mathrm{K}^{+}+\mathrm{Na}^{+}$was measured by flame atomic absorption spectrophotometry. $\mathrm{SO}_{4}{ }^{2-}, \mathrm{Cl}^{-}$, and $\mathrm{NO}_{3}{ }^{-}$were determined by ion chromatography, and $\mathrm{HCO}_{3}{ }^{-}$was determined by alkalinity titration.

For each groundwater sample, the computed ionic-balance-error (IBE) was observed to be within the acceptable limit of $\pm 5 \%$ and was calculated by Equation (1) to ensure the accuracy of the analysis [9,35]:

$$
\mathrm{IBE}=\frac{\sum \text { Cations }-\sum \text { Anions }}{\sum \text { Cations }+\sum \text { Anions }} \times 100 .
$$

All cations and anions were expressed in meq/L. The calculated results showed that the IBE varied from -4.43 to 4.04 .

\subsection{Water Quality Index (WQI)}

The water quality index (WQI) reduces water parameters to a single number to assess the overall water quality at a certain location, and was computed to evaluate whether groundwater samples were suitable for drinking [36,37]. WQI was calculated using the 12 measured parameters at each site, in three steps in the current study. The first step was to estimate the relative weight $\left(W_{i}\right)$ of each parameter, as given in Equation (2):

$$
W_{i}=\frac{w_{i}}{\sum_{i=1}^{n} w_{i}}
$$

where $w_{i}$ is the weight of each parameter, and $n$ is the number of hydrochemical parameters. The value of $w_{i}$ ranged from 1 to 5 according to the impact of the contaminant on human health [37]. The second step was to estimate the quality rating scale $\left(Q_{i}\right)$ of each parameter using Equation (3):

$$
Q_{i}=\frac{C_{i}-C_{i p}}{S_{i}-C_{i p}} \times 100
$$

where $C_{i}$ is the concentration of each parameter in $\mathrm{mg} / \mathrm{L}, S_{i}$ is the standard permissible value for the $i$ parameter in $\mathrm{mg} / \mathrm{L}$, and $C_{i p}$ is the ideal value of the $i$ parameter in pure water (consider $C_{j p}=0$ for all, except the $\mathrm{pH}$ value where $C_{j p}=7$ ). The third step was to calculate the WQI using Equation (4):

$$
W Q I=\sum_{i=1}^{n} W_{i} \times Q_{i} .
$$

The calculated values of $w_{i}, W_{i}$, and $S_{i}$ are shown in Table 1. 
Table 1. The values of $w_{i}, W_{i}$, and $S_{i}$ of different parameters. TDS, total dissolved solids; TH, total hardness; EC, electrical conductivity.

\begin{tabular}{cccccccccccc}
\hline Parameters & $\mathbf{k}^{+}+\mathbf{N a}^{++}$ & $\mathbf{C a}^{2+}$ & $\mathbf{M g}^{2++}$ & $\mathbf{C l}^{-}$ & $\mathbf{S O}_{4}{ }^{2-}$ & $\mathbf{H C O}_{3}{ }^{-}$ & $\mathbf{N O}_{3}{ }^{-}$ & $\mathbf{p H}$ & $\mathbf{T D S}$ & $\mathbf{T H}$ & $\mathbf{E C}$ \\
\hline$w_{i}$ & 2 & 3 & 3 & 4 & 3 & 3 & 5 & 3 & 5 & 3 & 4 \\
$W_{i}$ & 0.053 & 0.079 & 0.079 & 0.105 & 0.079 & 0.079 & 0.132 & 0.079 & 0.132 & 0.079 & 0.105 \\
$S_{i}$ & 200 & 200 & 150 & 250 & 250 & 500 & 20 & 8.5 & 1000 & 450 & 1500 \\
\hline
\end{tabular}

\subsection{Human Health Risk (HHR) Assessment via Water Pathway}

The HHR assessment, established by the United States Environmental Protection Agency (USEPA), is a widely used tool for evaluating human health risk $[11,12,18,35]$. The human body primarily absorbs contaminants via drinking water [14,38], and so only the health effects of contaminants introduced through drinking water were considered in the study region. Nitrate concentration was selected for HHR assessment in the current study. The chronic daily intake (CDI), hazard quotient (HQ), and the hazard index inducing from nitrate $\left(\mathrm{HI}_{\text {nitrate }}\right)$ were calculated by Equations (5) and (6), respectively. The detailed reference values of each parameter used for the calculation are presented in Table 2.

$$
\begin{gathered}
C D I=\frac{C_{w} \times I R \times E F \times E D}{B W \times A T} \\
H I_{\text {nitrate }}=H Q=\frac{C D I}{R f D}
\end{gathered}
$$

\begin{tabular}{|c|c|c|c|c|c|c|c|c|}
\hline Parameters & Units & $\begin{array}{c}\text { 6-12 } \\
\text { Months }\end{array}$ & $\begin{array}{c}6-11 \\
\text { Years }\end{array}$ & $\begin{array}{l}11-16 \\
\text { Years }\end{array}$ & $\begin{array}{l}16-18 \\
\text { Years }\end{array}$ & $\begin{array}{l}18-21 \\
\text { Years }\end{array}$ & $\begin{array}{l}21-65 \\
\text { Years }\end{array}$ & $\begin{array}{c}\geq 65 \\
\text { Years }\end{array}$ \\
\hline Ingestion rate (IR) & L/day & 1 & 1.32 & 1.82 & 1.78 & 2.34 & 2.94 & 2.73 \\
\hline Exposure frequency (EF) & day/year & 365 & 365 & 365 & 365 & 365 & 365 & 365 \\
\hline Exposure duration (ED) & year & 6 & 6 & 6 & 6 & 30 & 30 & 30 \\
\hline Body weight (BW) & $\mathrm{kg}$ & 9.1 & 29.3 & 54.2 & 67.6 & 67.6 & 78.8 & 80 \\
\hline Average time (AT) & days & 2190 & 2190 & 2190 & 2190 & 10,950 & 10,950 & 10,950 \\
\hline Concentration of element $\left(C_{w}\right)$ & $\mathrm{mg} / \mathrm{L}$ & \multicolumn{7}{|c|}{ Present study } \\
\hline Reference dose of nitrate (RfD) & - & & & & 1.6 & & & \\
\hline
\end{tabular}

Table 2. Key parameters for computing the exposure risk of nitrate through drinking water.

\section{Results and Discussion}

\subsection{Groundwater Chemistry}

\subsubsection{Physiochemical Parameters}

Table 3 lists descriptive statistical parameters ( $\min , \max$, and mean) for the analyzed groundwater samples of the study region. Table 3 also includes details of drinking water quality limits $\left(S_{i}\right)$, and the number and percentage of samples which exceeded the permissible limit in the absence of an alternate source (PLAAS). In this region, the $\mathrm{pH}$ of groundwater samples varied from 6.9 to 8.4 with a mean of 7.68. Ninety-eight percent of samples were alkaline, and all were within the recommended limits of 6.5-8.5 [39]. The TDS concentrations ranged from 110.7 to $2978.73 \mathrm{mg} / \mathrm{L}$ with a mean of $516.81 \mathrm{mg} / \mathrm{L}$, and fourteen samples ( $7.33 \%$ of total samples) exceed the recommended limit of $1000 \mathrm{mg} / \mathrm{L}$ for drinking water, as shown in Table 3. The TH concentration ranged from 1.96 to $530.5 \mathrm{mg} / \mathrm{L}$ with an average of $64.87 \mathrm{mg} / \mathrm{L}$, and $98.95 \%$ were within the standard limit $(450 \mathrm{mg} / \mathrm{L})$, indicating a suitable quality for drinking. EC is used to measure the ability of water to conduct an electric current, and an elevated EC reveals the enrichment of silt in water [12,40]. The EC of groundwater samples ranged from 201.26 to $4445.86 \mu \mathrm{S} / \mathrm{cm}$ with a mean of $885.75 \mu \mathrm{S} / \mathrm{cm}$, as shown in Table 3. Also, $90.05 \%$ of samples were below $1500 \mu \mathrm{S} / \mathrm{cm}$, indicating a low enrichment of salts in this area. 
Table 3. Statistical analysis of physiochemical parameters.

\begin{tabular}{cccccccc}
\hline Parameters & Units & Min. & Max. & Mean & $S_{i}$ & $\begin{array}{c}\text { Number of Samples } \\
\text { Exceeding the } \\
\text { PLAAS }\end{array}$ & $\begin{array}{c}\text { \% of Samples } \\
\text { Exceeding the } \\
\text { PLAAS }\end{array}$ \\
\hline $\mathrm{pH}$ & - & 6.9 & 8.4 & 7.68 & $6.5-8.5$ & 0 & 0.00 \\
$\mathrm{TDS}$ & $\mathrm{mg} / \mathrm{L}$ & 110.7 & 2978.73 & 516.81 & 1000 & 14 & 7.33 \\
$\mathrm{TH}$ & $\mathrm{mg} / \mathrm{L}$ & 1.96 & 530.5 & 64.87 & 450 & 2 & 1.05 \\
$\mathrm{EC}$ & $\mu \mathrm{S} / \mathrm{cm}$ & 201.26 & 4445.86 & 885.75 & 1500 & 19 & 9.95 \\
$\mathrm{k}^{+}+\mathrm{Na}^{+}$ & $\mathrm{mg} / \mathrm{L}$ & 2.07 & 400.89 & 102.12 & 200 & 34 & 17.80 \\
$\mathrm{Ca}^{2+}$ & $\mathrm{mg} / \mathrm{L}$ & 7.21 & 124.2 & 49.14 & 200 & 0 & 0.00 \\
$\mathrm{Mg}^{2+}$ & $\mathrm{mg} / \mathrm{L}$ & 1.2 & 293.57 & 31.91 & 150 & 3 & 1.57 \\
$\mathrm{Cl}^{-}$ & $\mathrm{mg} / \mathrm{L}$ & 2.48 & 1556.39 & 57.09 & 250 & 11 & 5.76 \\
$\mathrm{SO}_{4}{ }^{2-}$ & $\mathrm{mg} / \mathrm{L}$ & 0 & 634.97 & 70.01 & 250 & 12 & 16.28 \\
$\mathrm{HCO}_{3}{ }^{-}$ & $\mathrm{mg} / \mathrm{L}$ & 109.83 & 1020.22 & 374.79 & 500 & 31 & 24.61 \\
$\mathrm{NO}_{3}{ }^{-}$ & $\mathrm{mg} / \mathrm{L}$ & 0 & 90 & 18.26 & 20 & 47 & \\
\hline
\end{tabular}

PLAAS: permissible limit in the absence of an alternate source.

For cation chemistry, $\mathrm{K}^{+}+\mathrm{Na}^{+}$(mean $=102.12 \mathrm{mg} / \mathrm{L}$ ) were the dominant ions in the groundwater of the study region, followed by $\mathrm{Ca}^{2+}($ mean $=49.14 \mathrm{mg} / \mathrm{L})$ and $\mathrm{Mg}^{2+}($ mean $=31.91 \mathrm{mg} / \mathrm{L})$. The concentration of $\mathrm{K}^{+}+\mathrm{Na}^{+}$ranged from 2.07 to $400.89 \mathrm{mg} / \mathrm{L}$, and $17.80 \%$ of groundwater samples exceeded the acceptable limit of $200 \mathrm{mg} / \mathrm{L}$ for drinking. Cation exchange and frequent evaporation may be the main causes of the high $\mathrm{Na}^{+}$concentration in groundwater in the study region [11,41]. $\mathrm{Ca}^{2+}$ and $\mathrm{Mg}^{2+}$ are also key hydrochemical elements for human health in groundwater [42]. As shown in Table 3, $\mathrm{Ca}^{2+}$ differed from 7.21 to $124.2 \mathrm{mg} / \mathrm{L}$, indicating that all groundwater samples were under the standard limit of $200 \mathrm{mg} / \mathrm{L}$ [39]. The $\mathrm{Mg}^{2+}$ concentration ranged from 1.2 to $293.57 \mathrm{mg} / \mathrm{L}$, and three samples exceeded the recommended limit of $200 \mathrm{mg} / \mathrm{L}$ for drinking.

The average concentration of anions in all samples followed the order $\mathrm{HCO}_{3}{ }^{-}>\mathrm{SO}_{4}{ }^{2-}>\mathrm{Cl}^{-}>$ $\mathrm{NO}_{3}{ }^{-}$. The concentration of $\mathrm{HCO}_{3}{ }^{-}$varied from 109.83 to $1020.22 \mathrm{mg} / \mathrm{L}$ with a mean of $374.79 \mathrm{mg} / \mathrm{L}$. Mineral dissolution, which controls the groundwater chemistry, is the main reason for the high $\mathrm{HCO}_{3}{ }^{-}$ concentration [43]. In the present study, the concentration of $\mathrm{SO}_{4}{ }^{2-}$ ranged from 0 to $634.97 \mathrm{mg} / \mathrm{L}$, with an average of $70.01 \mathrm{mg} / \mathrm{L}$. The $\mathrm{Cl}^{-}$content varied from 2.48 to $1556.39 \mathrm{mg} / \mathrm{L}$ with a mean of $57.09 \mathrm{mg} / \mathrm{L}$. Overall, $6.28 \%$ and $5.76 \%$ of groundwater samples were within the acceptable limit of $250 \mathrm{mg} / \mathrm{L}$ for $\mathrm{SO}_{4}{ }^{2-}$ and $\mathrm{Cl}^{-}$in the study region, respectively. The $\mathrm{NO}_{3}{ }^{-}$content varied between 0 and $90 \mathrm{mg} / \mathrm{L}$ with a mean of $18.26 \mathrm{mg} / \mathrm{L}$. Forty-seven groundwater samples exceeded the standard limit of $20 \mathrm{mg} / \mathrm{L}$, indicating that $24.61 \%$ of groundwater samples in the study region were unsuitable for drinking, and nitrogen pollution was the most serious form of pollution.

\subsubsection{Hydrochemical Types of Groundwater}

Hydrochemical classifications of groundwater are governed by major ions. A Durov diagram, as shown in Figure 2, is a useful graphical tool that is widely used to identify the chemical relationship and evolution of groundwater samples $[38,44]$. As shown in Figure 2, the dominant hydrochemical facies of the groundwater samples were $\mathrm{HCO}_{3}-\mathrm{Na}$ and $\mathrm{HCO}_{3}-\mathrm{Ca}$. For cations, the majority of samples were also observed in $\mathrm{B}$ (no dominant), indicating that the cations were also predominated by the mixed type. Figure 2 reveals that more than $90 \%$ of groundwater samples had a TDS less than $1000 \mathrm{mg} / \mathrm{L}$ in which $\mathrm{HCO}_{3}{ }^{-}$was the main anion. Approximately $10 \%$ of groundwater samples were brackish water with TDS values ranging from 1000 to $3000 \mathrm{mg} / \mathrm{L}$. High nitrate concentrations [27] in this field were characterized by fresh water (TDS $<1000 \mathrm{mg} / \mathrm{L}$ ) [44], especially TDS values $<500 \mathrm{mg} / \mathrm{L}$. 


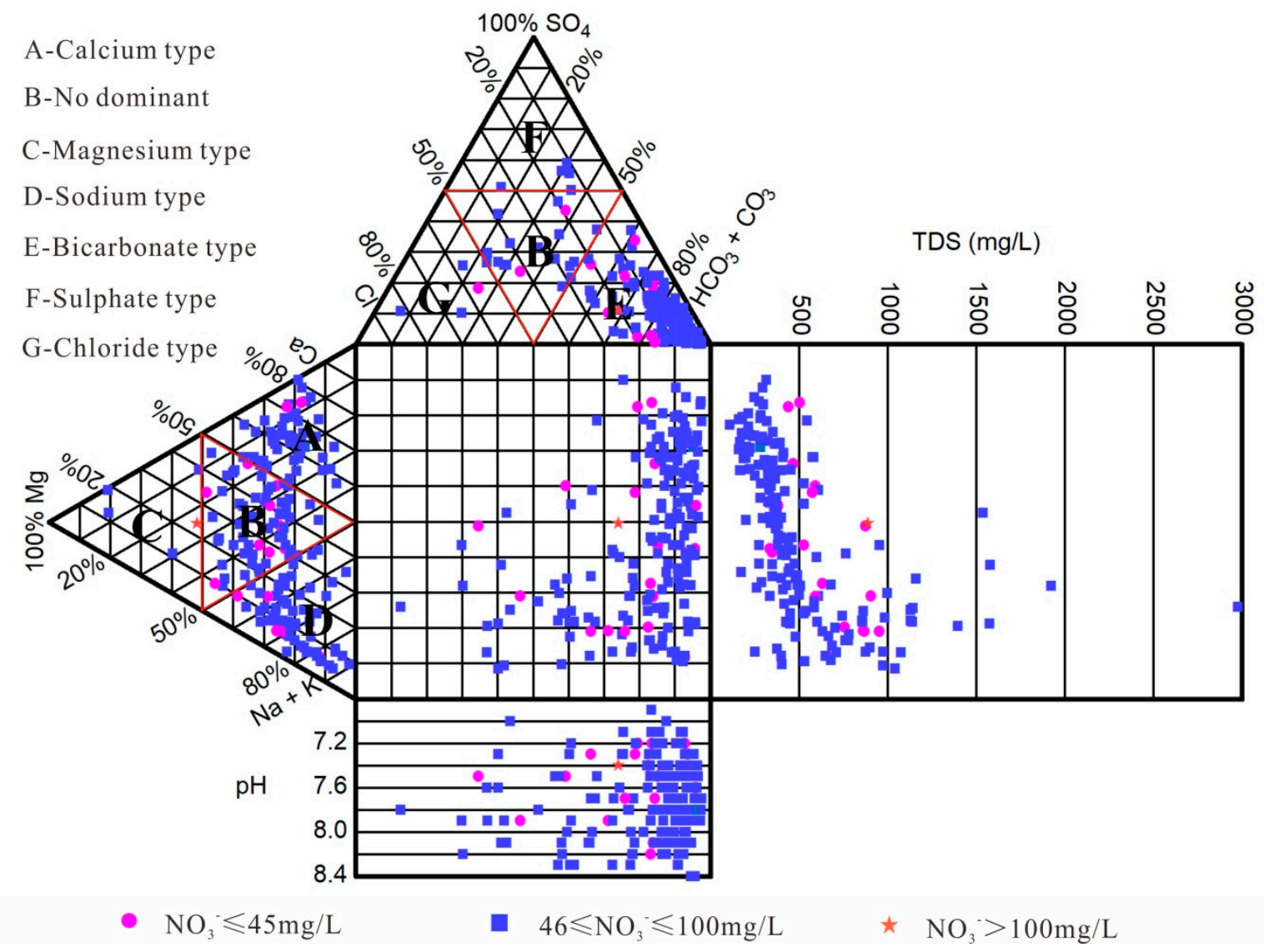

Figure 2. Durov diagram representing groundwater types.

\subsubsection{Mechanisms of Hydrogeochemistry}

Interactions between groundwater and aquifers can significantly affect water chemistry [45]. To determine the sources of major ions, bivariate diagrams were constructed for the groundwater samples in the study region, as shown in Figure 3. Generally, if halite dissolution was the only source of $\mathrm{Na}^{+}$and $\mathrm{Cl}^{-}$, the data points of groundwater samples were distributed along a 1:1 line. As shown in Figure 3a, the plot of $\mathrm{Na}^{+}$vs. $\mathrm{Cl}^{-}$shows a clear $\mathrm{Na}^{+}$enrichment in the groundwater samples, possibly due to halite dissolution, weathering of silicate minerals, and ion exchange $[9,13,46]$.

Gypsum weathering is a major process which contributes to the presence of $\mathrm{Ca}^{2+}$ in groundwater, and is the only source of $\mathrm{Ca}^{2+}$ and $\mathrm{SO}_{4}{ }^{2-}$ when the ratio of the two ions is approximately 1 [13]. As shown in the bivariate diagrams of $\mathrm{Ca}^{2+}$ and $\mathrm{SO}_{4}{ }^{2-}$ in Figure $3 \mathrm{~b}$, most samples were plotted below the 1:1 line, indicating that other sources contributed to the presence of $\mathrm{Ca}^{2+}$, such as the dissolution of calcite and dolomite [9,47]. In theory, if calcite and dolomite dissolution were the only sources of $\mathrm{Ca}^{2+}$ and $\mathrm{Mg}^{2+}$, the $\mathrm{HCO}_{3}^{-} /\left(\mathrm{Ca}^{2+}+\mathrm{Mg}^{2+}\right)$ ratio should lie from 1:1 to 2:1 depending on the amount of $\mathrm{CO}_{2}[46,47]$. The specific reactions involved in this process are as follows:

$$
\begin{gathered}
\mathrm{CaCO}_{3}+\mathrm{H}^{+} \leftrightarrow \mathrm{HCO}_{3}^{-}+\mathrm{Ca}^{2+} \\
\mathrm{CaCO}_{3}+\mathrm{H}_{2} \mathrm{O}+\mathrm{CO}_{2} \leftrightarrow 2 \mathrm{HCO}_{3}^{-}+\mathrm{Ca}^{2+} \\
\mathrm{CaMg}\left(\mathrm{CO}_{3}\right)_{2}+2 \mathrm{H}^{+} \leftrightarrow 2 \mathrm{HCO}_{3}^{-}+\mathrm{Ca}^{2+}+\mathrm{Mg}^{2+} \\
\mathrm{CaMg}\left(\mathrm{CO}_{3}\right)_{2}+2 \mathrm{H}_{2} \mathrm{O}+\mathrm{CO}_{2} \leftrightarrow 4 \mathrm{HCO}_{3}{ }^{-}+\mathrm{Ca}^{2+} \mathrm{Mg}^{2+}
\end{gathered}
$$



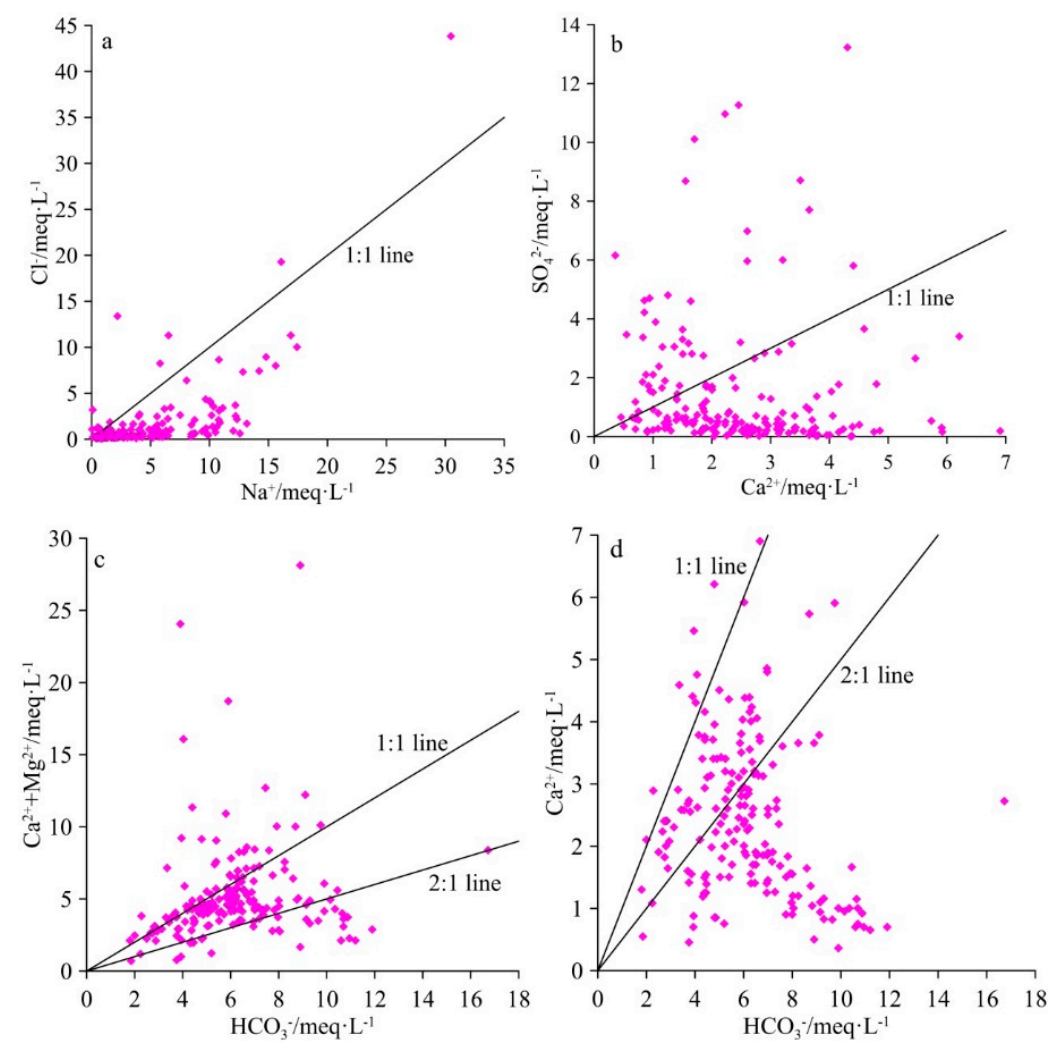

Figure 3. Bivariate diagrams of ionic concentrations in groundwater.

As shown in Figure $3 \mathrm{c}, \mathrm{HCO}_{3}{ }^{-} /\left(\mathrm{Ca}^{2+}+\mathrm{Mg}^{2+}\right)$ in most groundwater samples ranged from 1:1 to 2:1, indicating that the primary source of $\mathrm{Ca}^{2+}$ and $\mathrm{Mg}^{2+}$ was dolomite dissolution. However, more than half of the samples were plotted below the 2:1 line, as shown in Figure 3d, suggesting that the calcite dissolution had a minor effect on water chemistry. According to this result, the ratio of $\mathrm{Na}^{+} / \mathrm{Cl}^{-}$ exceeded 1, indicating that ion exchange between $\mathrm{Ca}^{2+}$ and $\mathrm{Na}^{+}$may have occurred and was responsible for the excess $\mathrm{HCO}_{3}{ }^{-}$. This ion exchange can be expressed as follows:

$$
\mathrm{Ca}^{2+}+2 \mathrm{NaX} \leftrightarrow \mathrm{CaX} 2+2 \mathrm{Na}^{+} .
$$

Ion exchange was also studied using the chloro-alkaline indices (CAI-I and CAI-II) proposed by [48]. CAI-I and CAI-II were calculated using Equations (12) and (13) to interpret the ion exchange behavior between groundwater and the prevailing environment [10]. All ions were expressed in meq/L.

$$
\begin{gathered}
\mathrm{CAI}-\mathrm{I}=\frac{\mathrm{Cl}^{-}-\left(\mathrm{Na}^{+}+\mathrm{K}^{+}\right)}{\mathrm{Cl} l^{-}} \\
\mathrm{CAI}-\mathrm{II}=\frac{\mathrm{Cl}^{-}-\left(\mathrm{Na}^{+}+\mathrm{K}^{+}\right)}{\mathrm{SO}_{4}^{2-}+\mathrm{HCO}_{3}{ }^{-}+\mathrm{CO}_{3}^{2-}+\mathrm{NO}_{3}^{-}}
\end{gathered}
$$

If CAI-I and CAI-II are negative, ion exchange occurred between $\mathrm{Ca}^{2+}$ or $\mathrm{Mg}^{2+}$ in the groundwater and $\mathrm{Na}^{+}$and $\mathrm{K}^{+}$in the rocks or soil, and a reverse ion exchange occurred when positive values of CAI-I and CAI-II were obtained [4,10]. The CAI-I and CAI-II values obtained in this study are shown in Figure 4 . The results revealed that $92.67 \%$ of groundwater samples possessed negative CAI-I and CAI-II values, indicating that ion exchange may have occurred between $\mathrm{Ca}^{2+} \mathrm{or} \mathrm{Mg}^{2+}$ in the groundwater and $\mathrm{Na}^{+}$and $\mathrm{K}^{+}$in the rocks or soil. 


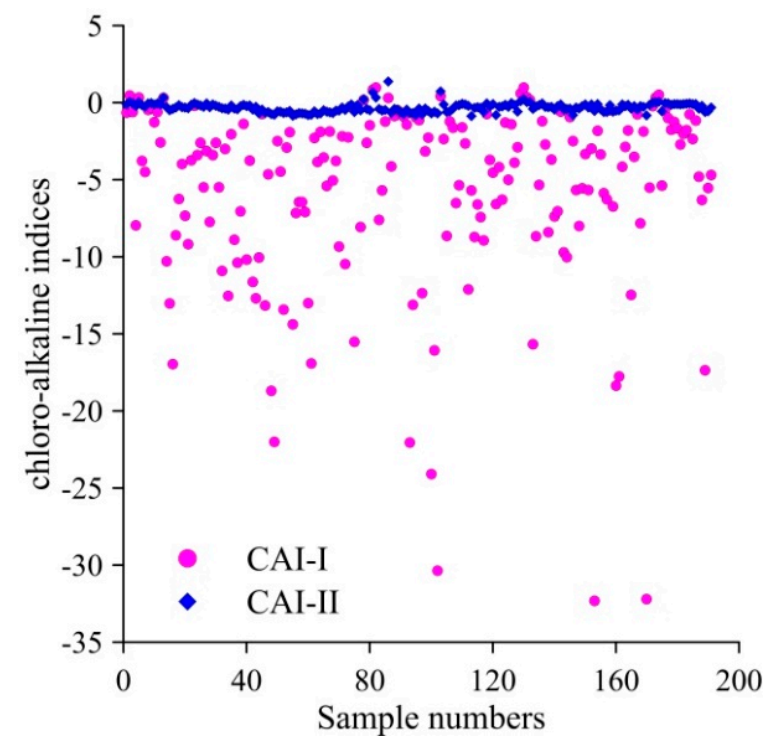

Figure 4. Scatter diagram of the chloro-alkaline indices (CAI-I and CAI-II) of groundwater samples in the study region.

\subsection{Groundwater Quality for Drinking}

The water quality index (WQI) was used to assess the groundwater quality for drinking in this study. Groundwater quality can be classified into five categories [13] based on the WQI value: excellent (WQI $<25)$, good $(25<\mathrm{WQI}<50)$, poor $(50<\mathrm{WQI}<100)$, very poor $(100<\mathrm{WQI}<150)$, and unsuitable for drinking (WQI $>150$ ). As shown in Figure 5, the groundwater quality ranged from excellent to extremely poor. The groundwater in the Guanzhong Basin primarily contains good and medium-quality water. The good quality water was mainly located south of the Wei River, while the medium water was mainly distributed north of the Wei River. Small amounts of poor and extremely poor water were scattered throughout the area northwest of Xianyang City, and some excellent water was scattered south of the Wei River. It can be seen that the groundwater south of the Wei River was better than that north of the Wei River, which was mainly related to the topography and agriculture of the Guanzhong Basin. Specifically, there is a lower population and less agriculture south of the Wei River than north of the Wei River, primarily due to the presence of the Qinling Mountains. Additionally, the surface water system is more developed and groundwater usage is lower in the southern mountainous areas, so the probability of usage of polluted groundwater is relatively lower.

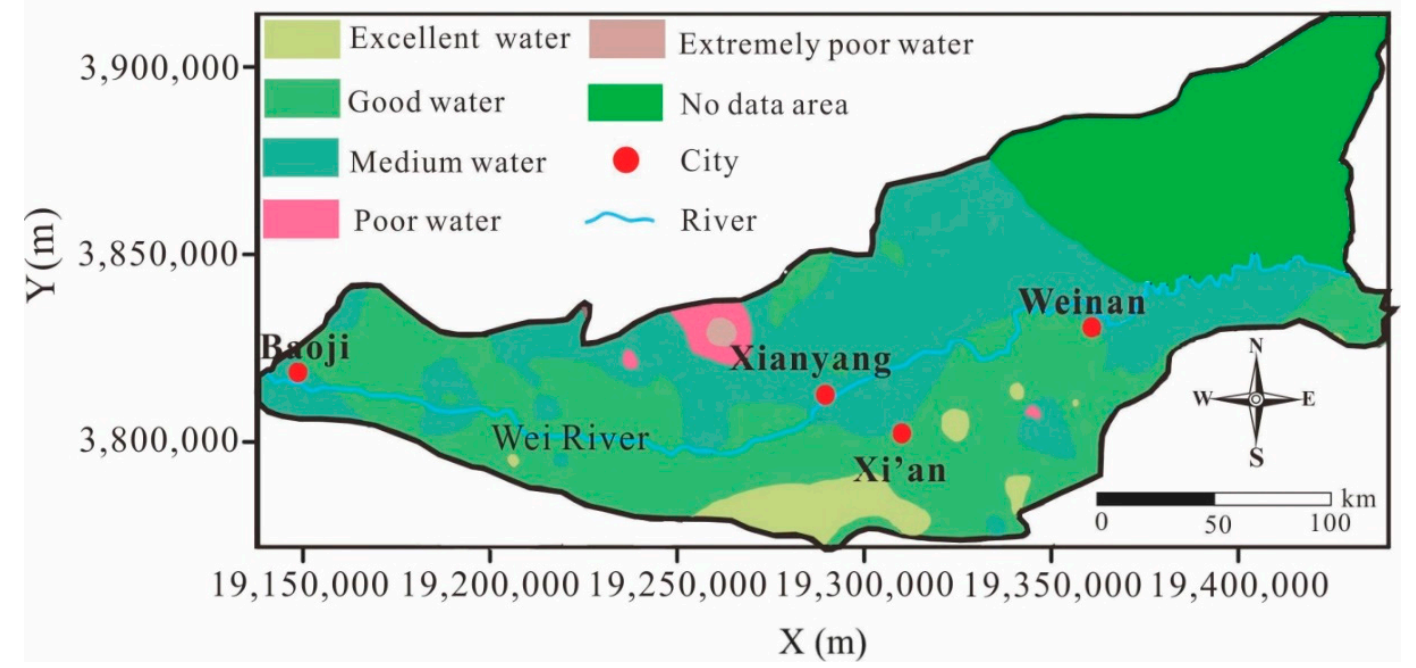

Figure 5. Distribution of the water quality index (WQI) in the groundwater of the study region. 


\subsection{Distribution and Occurrence of Nitrate}

The groundwater nitrate concentration maps in Figure 6 show that high nitrate concentrations are distributed mainly in the area north of the Wei River, likely due to the higher population in this region. The nitrate contamination may originate from many human activities, such as the extensive use of fertilizers, manures, and insecticides in agriculture, septic tank leakage, and organic matter effluents [12]. The use of agricultural fertilizers was the principal cause for higher $\mathrm{NO}_{3}{ }^{-}$concentration in the groundwater of the study region. In addition, among the 191 groundwater samples, 47 samples had $\mathrm{NO}_{3}{ }^{-}$concentrations higher than the standard limit of $20 \mathrm{mg} / \mathrm{L}$, as shown in Table 3. The low nitrate concentration in groundwater in the area south of $\mathrm{Xi}^{\prime}$ an is that the main drinking water in $X i^{\prime}$ an is surface water, which has a lower impact on groundwater. Additionally, industrial ammonia nitrogen also contributed to the nitrate concentration in Guanzhong. Wan [49] studied the temporal and spatial variation of mineral nitrogen pollution in groundwater in the Guanzhong Basin and found that variations in industrial ammonia nitrogen emissions were consistent with changes in the nitrate content in groundwater. It can be seen that agricultural activities had a greater effect than industry on the nitrate content in groundwater in the Guanzhong Basin. Moreover, according to the levels of nitrate risk defined in [27], the percentages of low risk ( $<45 \mathrm{mg} / \mathrm{L})$, high risk $(45-100 \mathrm{mg} / \mathrm{L})$, and very high risk (>100 mg/L) were $90.58 \%, 8.9 \%$, and $0.52 \%$, respectively. The concentration of nitrate in the study area poses a great risk to human drinking water. Some studies $[14,50,51]$ have indicated that long-term drinking of high-nitrate groundwater can cause methemoglobinemia in humans.

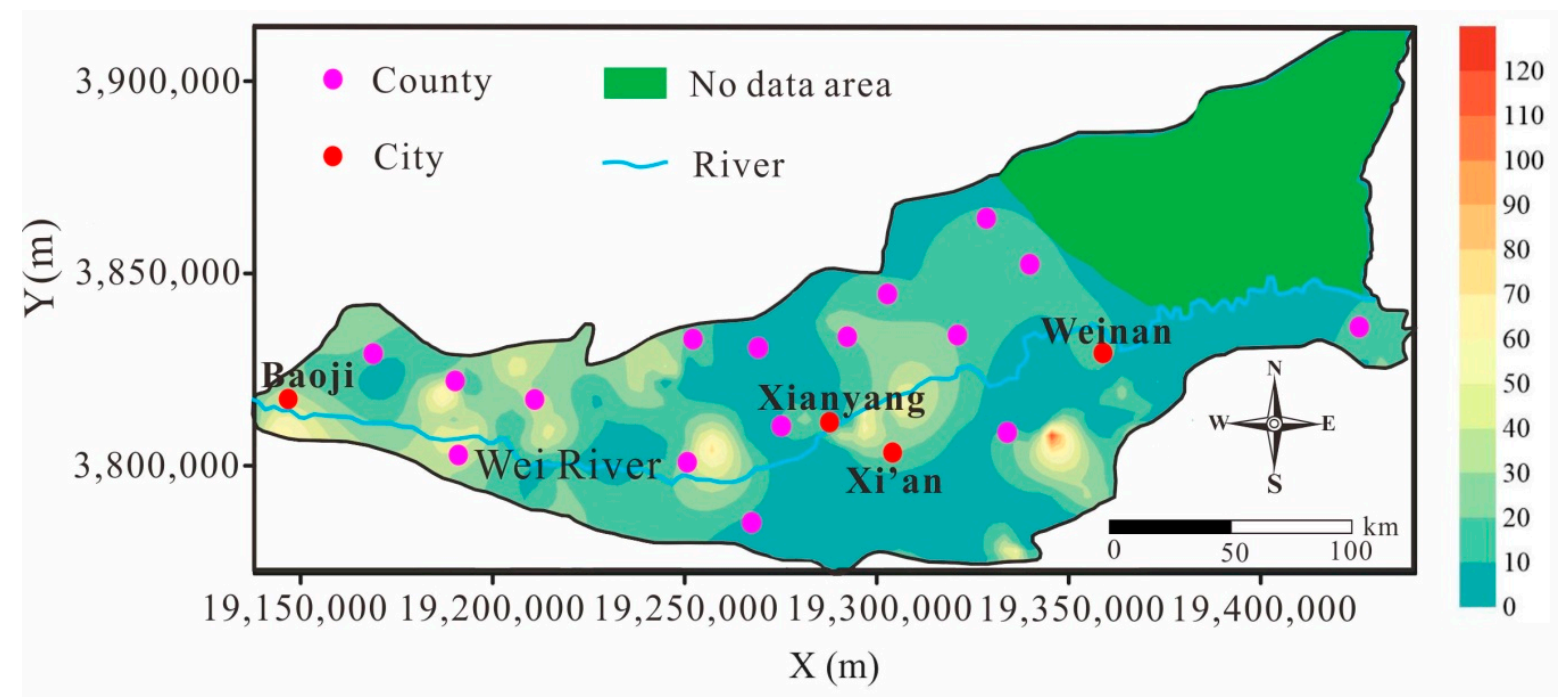

Figure 6. Spatial distribution map of $\mathrm{NO}_{3}{ }^{-}$in the Guanzhong Basin, China.

\subsection{Evaluation of Human Health Risk (HHR)}

The total hazard indices $\left(\mathrm{HI}_{\mathrm{total}}\right)$ associated with nitrate concentration via ingestion were estimated for different age groups (6-12 months, 6-11 years, 11-16 years, 16-18 years, 18-21 years, 21-65 years, and $\geq 65$ years). The statistical results of non-carcinogenic health risks are shown in Table 4 . The $H I_{\text {total }}$ values ranged from 0.006868 to 13.0495 with a mean of 1.129466 for 6-12 months. The $H I_{\text {total }}$ values for age $6-11$ years varied from 0.002816 to 5.34983 with an average of 0.463043 . The values for age $11-16$ years, $16-18$ years, $18-21$ years, $21-65$ years, and $\geq 65$ years ranged from 0.002099 to $3.98755,0.001646$ to $3.12685,0.002163$ to $4.11058,0.002332$ to 4.43052 , and 0.002133 to 4.05234 , respectively. The obtained $H I_{\text {total }}$ values showed that 69 groundwater samples exceeded the acceptable limit $H I=1$ for the 6-12 months group, while 26,18 , and 8 groundwater samples exceeded the acceptable limit for 6-11 years, $11-16$ years, and $16-18$ years age groups, respectively. In addition, for $18-21$ years, $21-65$ years, and $\geq 65$ years, 18,22 , and 18 samples exceeded the acceptable limit, and their means were $0.355782,0.383474$, and 0.350742 , respectively. The HHR results indicated that the 6-12 month age group was more likely 
to suffer from health complications due to a higher nitrate concentration, followed by 6-11 years, 21-65 years, 18-21 years, $\geq 65$ years, $11-16$ years, and 16-18 years age groups based on the mean values. This order is mainly related to the discrepancy of exposure parameters [27]. Figure 7 was plotted to show details of the results of non-carcinogenic health risk for different age groups.

Table 4. The statistical results of non-carcinogenic health risks in the study region.

\begin{tabular}{cccccc}
\hline HI $_{\text {total }}$ & Max. & Min. & Mean & Num. & Per. \\
\hline 6-12 months & 13.0495 & 0.006868 & 1.129466 & 69 & $36.13 \%$ \\
6-11 years & 5.34983 & 0.002816 & 0.463043 & 26 & $13.61 \%$ \\
11-16 years & 3.98755 & 0.002099 & 0.345133 & 18 & $9.42 \%$ \\
16-18 years & 3.12685 & 0.001646 & 0.270637 & 8 & $4.19 \%$ \\
18-21 years & 4.11058 & 0.002163 & 0.355782 & 18 & $9.42 \%$ \\
21-65 years & 4.43052 & 0.002332 & 0.383474 & 22 & $11.52 \%$ \\
$\geq 65$ years & 4.05234 & 0.002133 & 0.350742 & 18 & $9.42 \%$ \\
\hline
\end{tabular}

Num.: the number of groundwater samples exceeding the acceptable limit of $\mathrm{HI}=1$; Per.: a percentage of the number of water samples exceeding the acceptable limit of $\mathrm{HI}=1$ relative to the number of all groundwater samples. HI, hazard index.

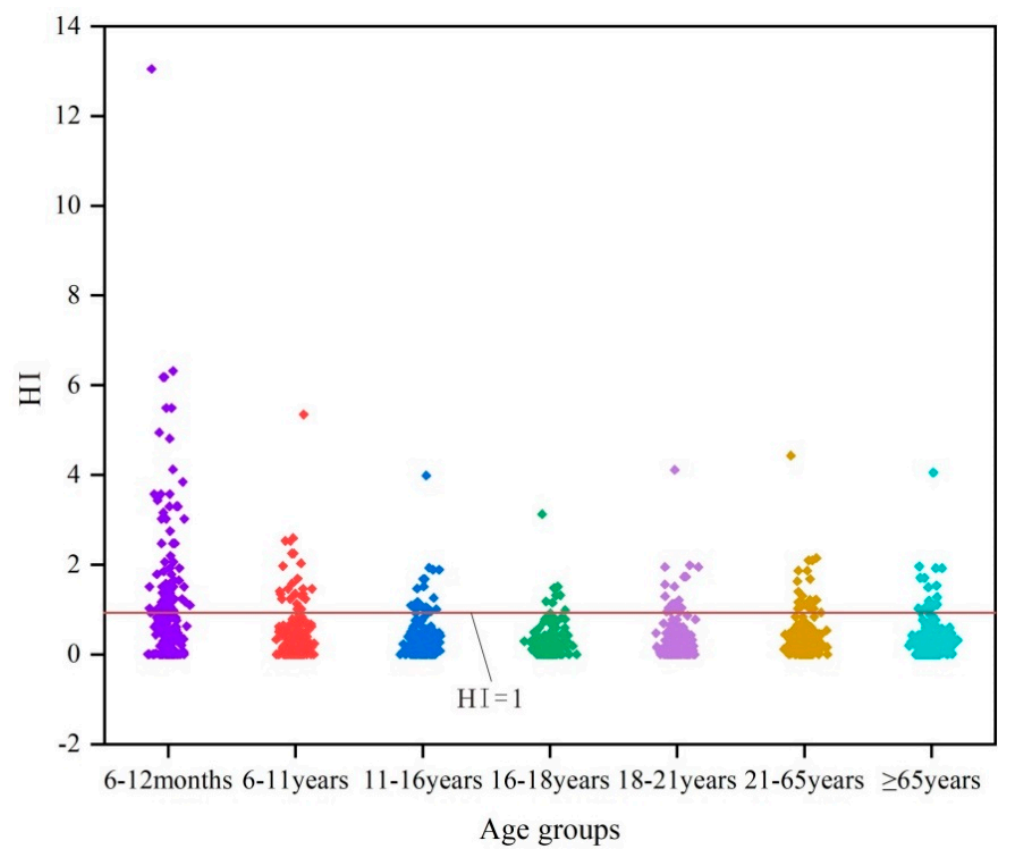

Figure 7. The results of non-carcinogenic health risk for different age groups.

Moreover, a percentage bar graph of the hazard indices of the different age groups exceeding the acceptable limit of $\mathrm{HI}=1$ is shown in Figure 8. As shown in Figure 8, the same nitrate content in groundwater had different effects on the non-carcinogenic risks in different age groups, which ranged from high to low as: 6-12 months $>6-11$ years $>21-65$ years $>18-21$ years $>\geq 65$ years $>11-16$ years $>16-18$ years. This may be related to the body's immunity and metabolism of different age groups. These results are especially useful for decision makers and will provide them with general risk information to help make proper decisions. Safe drinking water should be supplied for local residents and groundwater management should be further implemented in the study region. 


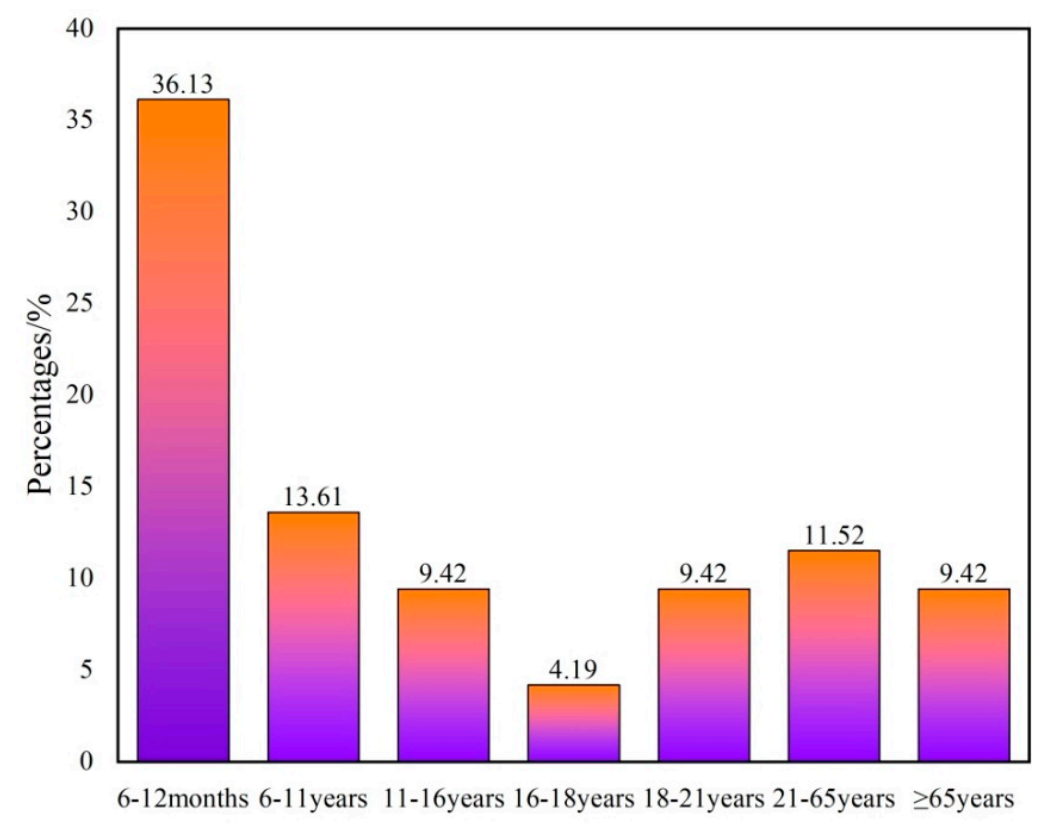

Age groups

Figure 8. Percentage bar graph of the hazard indices of the different age groups exceeding the acceptable limit of $\mathrm{HI}=1$.

\subsection{Sustainable Groundwater Quality Management}

Due to the importance of groundwater for maintaining the life of humans and plants, the sustainable development and management of groundwater resources is critical, especially in poor water quality zones. The results of groundwater quality and human health risk assessments have indicated that groundwater in the study region is not totally suitable for human consumption. Therefore, some management strategies are recommended to improve the groundwater quality, reduce the human health risk, and enhance the sustainable groundwater quality management in the study area [35].

- The use of large-scale fertilizers has resulted in nitrogen pollution in the study area, so reducing the use of fertilizers, such as using organic fertilizers, is crucial for reducing nitrogen pollution.

- Since industrial ammonia nitrogen emissions are one of the main sources of nitrogen pollution in the study area, effective treatment of industrial ammonia nitrogen after discharge is necessary, such as industrial nitrogen fixation.

- Additionally, strengthening scientific research, improving the monitoring network, and enhancing cooperation and data sharing are important and necessary for ensuring the sustainable development of groundwater [52].

- In this paper, regrettably, surface water samples were not obtained, so there is no comparative analysis of the relationship and changes between surface water quality and groundwater quality, and it is hoped that supplementary research can be carried out in the future.

\section{Conclusions}

In this study, various physiochemical parameters of 191 groundwater samples were analyzed to understand the geochemistry of groundwater and nitrate contamination and the health risks it poses to inhabitants of the Guanzhong Basin, China. The outcomes of the study can be summarized as follows:

1. $\mathrm{HCO}_{3}-\mathrm{Na}$ and $\mathrm{HCO}_{3}$-Ca species were the dominant hydrochemical facies in the groundwater samples in the study region. Bivariate diagrams and chloro-alkaline indices were used to study the hydrogeochemistry mechanisms. The results showed that halite dissolution, the weathering of silicate minerals, and ion exchange were the major sources responsible for 
$\mathrm{Na}^{+}$abundance. Gypsum weathering and dolomite dissolution were the major processes controlling the $\mathrm{Ca}^{2+}$ concentration, while dolomite dissolution was the primary source of $\mathrm{Mg}^{2+}$. Moreover, ion exchange between $\mathrm{Ca}^{2+}$ or $\mathrm{Mg}^{2+}$ in the groundwater with $\mathrm{Na}^{+}$and $\mathrm{K}^{+}$in the rocks or soil may have occurred in the groundwater of the study region.

2. The groundwater in the Guanzhong Basin predominantly contains good and medium-quality water. The good water was mainly distributed in the area south of the Wei River, while the medium-quality water was mainly distributed in the area north of the Wei River. Very little poor water or extremely poor water was found in the northwest of Xianyang City, and some excellent water was scattered throughout the area south of the Wei River. Generally, the groundwater in the area south of the Wei River was better than that in the area north of the Wei River.

3. High nitrate areas were mainly distributed in the area north of the Wei River. The nitrate contamination potentially originated from a large number of human activities, such as the extensive use of fertilizers, manures, and insecticide in agriculture, septic tank leakage, and organic matter effluent. Moreover, industrial ammonia nitrogen also played a role in the pollution of nitrate contamination in Guanzhong. Additionally, the percentages of low risk ( $<45 \mathrm{mg} / \mathrm{L})$, high risk $(45-100 \mathrm{mg} / \mathrm{L})$, and very high risk for nitrate pollution $(>100 \mathrm{mg} / \mathrm{L})$ were $90.58 \%, 8.9 \%$, and $0.52 \%$, respectively.

4. The HHR results indicated that the 6-12 month age group was more likely to suffer from health complications due to a higher nitrate concentration, followed by 6-11 years, 21-65 years, 18-21 years, $\geq 65$ years, $11-16$ years, and 16-18 years age groups based on the average values. These results are especially useful for decision makers and will provide them with general risk information to allow them to make appropriate decisions.

Author Contributions: Conceptualization, H.Q. and Q.Z.; Data curation, Q.Z. and P.X.; Formal analysis, Q.Z.; Funding acquisition, H.Q.; Methodology, Q.Z.; Software, Q.Z. and P.X.; Supervision, H.Q.; Writing-original draft preparation, Q.Z.; Writing-review and editing, H.Q. and P.X.

Funding: We are grateful for the support from the National Natural Science Foundation of China (41572236 and 41931285).

Acknowledgments: This study was financially supported by the National Natural Science Foundation of China (Grant No. 41572236 and 41931285). The completion of this article was inseparable from the contributions of all authors. Their support is gratefully acknowledged.

Conflicts of Interest: The authors declare no conflict of interest.

\section{References}

1. Li, P.; Qian, H. Water Resources Research to Support a Sustainable China; Routledge: Abingdon, UK, 2018.

2. Anantha, R.V.; Chandrakanta, G. Major ion chemistry, hydro-geochemical studies and mapping of variability in ground water quality of Sitanadi basin, Southern Karnataka. Octa J. Environ. Res. 2014, 2, 178-196.

3. Martos-Rosillo, S.; Marín-Lechado, C.; Pedrera, A.; Vadillo, I.; Motyka, J.; Molina, J.L.; Ortiz, P.; Ramírez, J. Methodology to evaluate the renewal period of carbonate aquifers: A key tool for their management in arid and semiarid regions, with the example of Becerrero aquifer, Spain. Hydrogeol. J. 2014, 22, 679-689. [CrossRef]

4. Wang, L.; Dong, Y.; Xie, Y.; Song, F.; Wei, Y.; Zhang, J. Distinct groundwater recharge sources and geochemical evolution of two adjacent sub-basins in the lower Shule River Basin, northwest China. Hydrogeol. J. 2016, 24, 1967-1979. [CrossRef]

5. Shiklomanov, I. Appraisal and assessment of world water resources. Water Int. 2000, 25, 11-32. [CrossRef]

6. Robertson, W.M.; Sharp, J.M. Estimates of recharge in two arid basin aquifers: A model of spatially variable net infiltration and its implications (Red Light Draw and Eagle Flats, Texas, USA). Hydrogeol. J. 2013, 21, 1853-1864. [CrossRef]

7. Ray, R.K.; Syed, T.H.; Saha, D.; Sarkar, B.C.; Patre, A.K. Assessment of village-wise groundwater draft for irrigation: A field-based study in hard-rock aquifers of central India. Hydrogeol. J. 2017, 25, 2513-2525. [CrossRef] 
8. Li, P.Y.; Tian, R.; Xue, C.Y.; Wu, J.H. Progress, opportunities, and key fields for groundwater quality research under the impacts of human activities in China with a special focus on western China. Environ. Sci. Pollut. Res. 2017, 24, 13224-13234. [CrossRef]

9. Xu, P.P.; Feng, W.W.; Qian, H.; Zhang, Q.Y. Hydrogeochemical Characterization and Irrigation Quality Assessment of Shallow Groundwater in the Central-Western Guanzhong Basin, China. Int. J. Environ. Res. Public Health 2019, 16, 1492. [CrossRef]

10. Islam, M.A.; Zahid, A.; Rahman, M.M.; Rahman, M.S.; Islam, M.J.; Akter, Y.; Shammi, M.; Bodrud-Doza, M.; Roy, B. Investigation of Groundwater Quality and Its Suitability for Drinking and Agricultural Use in the South Central Part of the Coastal Region in Bangladesh. Expo. Health 2017, 9, 27-41. [CrossRef]

11. Li, P.Y.; Li, X.Y.; Meng, X.Y.; Li, M.N.; Zhang, Y.T. Appraising Groundwater Quality and Health Risks from Contamination in a Semiarid Region of Northwest China. Expo. Health 2016, 8, 361-379. [CrossRef]

12. Adimalla, N.; Li, P.Y.; Qian, H. Evaluation of groundwater contamination for fluoride and nitrate in semi-arid region of Nirmal Province, South India: A special emphasis on human health risk assessment (HHRA). Hum. Ecol. Risk Assess. 2019, 25, 1107-1124. [CrossRef]

13. Li, P.Y.; Wu, J.H.; Qian, H.; Lyu, X.S.; Liu, H.W. Origin and assessment of groundwater pollution and associated health risk: A case study in an industrial park, northwest China. Environ. Geochem. Health 2014, 36, 693-712. [CrossRef] [PubMed]

14. Narsimha, A.; Rajitha, S. Spatial distribution and seasonal variation in fluoride enrichment in groundwater and its associated human health risk assessment in Telangana State, South India. Hum. Ecol. Risk Assess. 2018, 24, 2119-2132. [CrossRef]

15. Paladino, O.; Seyedsalehi, M.; Massabo, M. Probabilistic risk assessment of nitrate groundwater contamination from greenhouses in Albenga plain (Liguria, Italy) using lysimeters. Sci. Total Environ. 2018, 634, 427-438. [CrossRef] [PubMed]

16. Wu, J.; Zhao, W.D.; Lu, J.; Jin, S.; Wang, J.Q.; Qian, J.Z. Geographic information system based approach for the investigation of groundwater nitrogen pollution near a closed old landfill site in Beijing, China. Environ. Eng. Manag. J. 2018, 17, 1095-1101.

17. Wu, J.; Lu, J.; Wen, X.H.; Zhang, Z.H.; Lin, Y.C. Severe Nitrate Pollution and Health Risks of Coastal Aquifer Simultaneously Influenced by Saltwater Intrusion and Intensive Anthropogenic Activities. Arch. Environ. Contam. Toxicol. 2019, 77, 79-87. [CrossRef]

18. Adimalla, N.; Li, P.Y. Occurrence, health risks, and geochemical mechanisms of fluoride and nitrate in groundwater of the rock-dominant semi-arid region, Telangana State, India. Hum. Ecol. Risk Assess. 2019, 25, 81-103. [CrossRef]

19. Nejatijahromi, Z.; Nassery, H.R.; Hosono, T.; Nakhaei, M.; Alijani, F.; Okumura, A. Groundwater nitrate contamination in an area using urban wastewaters for agricultural irrigation under arid climate condition, southeast of Tehran, Iran. Agric. Water Manag. 2019, 221, 397-414. [CrossRef]

20. Zhang, Y.T.; Wu, J.H.; Xu, B. Human health risk assessment of groundwater nitrogen pollution in Jinghui canal irrigation area of the loess region, northwest China. Environ. Earth Sci. 2018, 77, 12. [CrossRef]

21. Liang, J.; Li, Z.; Yang, Q.; Lei, X.; Kang, A.; Li, S. Specific vulnerability assessment of nitrate in shallow groundwater with an improved DRSTIC-LE model. Ecotoxicol. Environ. Saf. 2019, 174, 649-657. [CrossRef]

22. Du, J.; Shi, C.-X. Effects of climatic factors and human activities on runoff of the Weihe River in recent decades. Quat. Int. 2012, 282, 58-65. [CrossRef]

23. Li, P.Y.; Qian, H.; Howard, K.W.F.; Wu, J.H. Building a new and sustainable "Silk Road economic belt". Environ. Earth Sci. 2015, 74, 7267-7270. [CrossRef]

24. Sun, Y.; Wang, W.; Duan, L.; Zhang, C.; Wang, Y. Geochemical evolution mechanisms of shallow Groundwater in Guanzhong basin, China. Hydrogeol. Eng. Geol. 2014, 41, 29-35.

25. Zuo, D.; Xu, Z.; Wu, W.; Zhao, J.; Zhao, F.J.W. Identification of streamflow response to climate change and human activities in the Wei River Basin, China. Water Resour. Manag. 2014, 28, 833-851. [CrossRef]

26. Kong, F.; Song, J.; Zhang, Y.; Fu, G.; Cheng, D.; Zhang, G.; Xue, Y.J.G. Surface Water-Groundwater Interaction in the Guanzhong Section of the Weihe River Basin, China. Graundwater 2019, 57, 647-660. [CrossRef] [PubMed]

27. Adimalla, N.; Qian, H. Hydrogeochemistry and fluoride contamination in the hard rock terrain of central Telangana, India: Analyses of its spatial distribution and health risk. SN Appl. Sci. 2019, 1, 202. [CrossRef] 
28. Xu, P.P.; Zhang, Q.Y.; Qian, H.; Li, M.N.; Hou, K. Characterization of geothermal water in the piedmont region of Qinling Mountains and Lantian-Bahe Group in Guanzhong Basin, China. Environ. Earth Sci. 2019, 78, 17. [CrossRef]

29. Xu, P.P.; Li, M.N.; Qian, H.; Zhang, Q.Y.; Liu, F.X.; Hou, K. Hydrochemistry and geothermometry of geothermal water in the central Guanzhong Basin, China: A case study in Xian. Environ. Earth Sci. 2019, 78, 20. [CrossRef]

30. Wang, W.K.; Zhang, Z.Y.; Duan, L.; Wang, Z.F.; Zhao, Y.Q.; Zhang, Q.; Dai, M.L.; Liu, H.Z.; Zheng, X.Y.; Sun, Y.B. Response of the groundwater system in the Guanzhong Basin (central China) to climate change and human activities. Hydrogeol. J. 2018, 26, 1429-1441. [CrossRef]

31. Ma, Z.Y.; Li, X.C.; Zheng, H.J.; Li, J.B.; Pei, B.; Guo, S.; Zhang, X.L. Origin and Classification of Geothermal Water from Guanzhong Basin, NW China: Geochemical and Isotopic Approach. J. Earth Sci. 2017, 28, 719-728. [CrossRef]

32. Jia, Z.F.; Ma, Y.D.; Liu, P.; Yao, C.C. Relationship between sand dew and plant leaf dew and its significance in irrigation water supplementation in Guanzhong Basin, China. Environ. Earth Sci. 2019, 78, 10. [CrossRef]

33. Li, P.Y.; Feng, W.; Xue, C.Y.; Tian, R.; Wang, S.T. Spatiotemporal Variability of Contaminants in Lake Water and Their Risks to Human Health: A Case Study of the Shahu Lake Tourist Area, Northwest China. Expo. Health 2017, 9, 213-225. [CrossRef]

34. Duan, L.; Wang, W.K.; Sun, Y.B.; Zhang, C.C. Iodine in groundwater of the Guanzhong Basin, China: Sources and hydrogeochemical controls on its distribution. Environ. Earth Sci. 2016, 75, 11. [CrossRef]

35. Adimalla, N.; Wu, J.H. Groundwater quality and associated health risks in a semi-arid region of south India: Implication to sustainable groundwater management. Hum. Ecol. Risk Assess. 2019, 25, 191-216. [CrossRef]

36. Horton, R.K. An index number system for rating water quality. J. Water Pollut. Control Fed. 1965, 37, 300-306.

37. Rabeiy, R.E. Assessment and modeling of groundwater quality using WQI and GIS in Upper Egypt area. Environ. Sci. Pollut. Res. 2018, 25, 30808-30817. [CrossRef] [PubMed]

38. Li, P.; He, X.; Li, Y.; Xiang, G. Occurrence and Health Implication of Fluoride in Groundwater of Loess Aquifer in the Chinese Loess Plateau: A Case Study of Tongchuan, Northwest China. Expo. Health 2019, 11, 95-107. [CrossRef]

39. WHO. Guidelines for Drinking Water Quality: Fourth Edition Incorporating the First Addendum; World Health Organization: Geneva, Switzerland, 2017.

40. Adimalla, N.; Marsetty, S.K.; Xu, P. Assessing groundwater quality and health risks of fluoride pollution in the Shasler Vagu (SV) watershed of Nalgonda, India. Hum. Ecol. Risk Assess. Int. J. 2019, 1-20. [CrossRef]

41. Oinam, J.D.; Ramanathan, A.L.; Singh, G. Geochemical and statistical evaluation of groundwater in Imphal and Thoubal district of Manipur, India. J. Asian Earth Sci. 2012, 48, 136-149. [CrossRef]

42. Razowska-Jaworek, L. Calcium and Magnesium in Groundwater: Occurrence and Significance for Human Health; CRC Press: Boca Raton, FL, USA, 2014.

43. Rao, N.S.; Sunitha, B.; Rambabu, R.; Rao, P.N.; Rao, P.S.; Spandana, B.D.; Sravanthi, M.; Marghade, D. Quality and degree of pollution of groundwater, using PIG from a rural part of Telangana State, India. Appl. Water Sci. 2018, 8, 227. [CrossRef]

44. Chen, J.; Huang, Q.W.; Lin, Y.L.; Fang, Y.; Qian, H.; Liu, R.P.; Ma, H.Y. Hydrogeochemical Characteristics and Quality Assessment of Groundwater in an Irrigated Region, Northwest China. Water 2019, 11, 96. [CrossRef]

45. Barzegar, R.; Moghaddam, A.A.; Tziritis, E.; Fakhri, M.S.; Soltani, S. Identification of hydrogeochemical processes and pollution sources of groundwater resources in the Marand plain, northwest of Iran. Environ. Earth Sci. 2017, 76, 297. [CrossRef]

46. Li, P.Y.; Wu, J.H.; Tian, R.; He, S.; He, X.D.; Xue, C.Y.; Zhang, K. Geochemistry, Hydraulic Connectivity and Quality Appraisal of Multilayered Groundwater in the Hongdunzi Coal Mine, Northwest China. Mine Water Environ. 2018, 37, 222-237. [CrossRef]

47. Wu, J.; Li, P.; Qian, H.; Duan, Z.; Zhang, X. Using correlation and multivariate statistical analysis to identify hydrogeochemical processes affecting the major ion chemistry of waters: A case study in Laoheba phosphorite mine in Sichuan, China. Arab. J. Geosci. 2014, 7, 3973-3982. [CrossRef]

48. Schoeller, H. Qualitative evaluation of groundwater resources. Methods and Techniques of Groundwater Investigations and Development; UNESCO: Paris, France, 1965; Volume 5483.

49. Wan, Z. Temporal and Spatial Variation of Mineral Nitrogen Pollution in Groundwater in Guanzhong Basin, Shanxi Province. Master's Thesis, Northwest A\&F University, Yangling, China, 2018. 
50. Wu, J.H.; Sun, Z.C. Evaluation of Shallow Groundwater Contamination and Associated Human Health Risk in an Alluvial Plain Impacted by Agricultural and Industrial Activities, Mid-West China. Expo. Health 2016, 8, 311-329. [CrossRef]

51. Rina, K.; Datta, P.S.; Singh, C.K.; Mukherjee, S. Determining the genetic origin of nitrate contamination in aquifers of Northern Gujarat, India. Environ. Earth Sci. 2014, 71, 1711-1719. [CrossRef]

52. Li, P.Y.; Qian, H.; Wu, J.H. Conjunctive use of groundwater and surface water to reduce soil salinization in the Yinchuan Plain, North-West China. Int. J. Water Resour. Dev. 2018, 34, 337-353. [CrossRef]

(C) 2019 by the authors. Licensee MDPI, Basel, Switzerland. This article is an open access article distributed under the terms and conditions of the Creative Commons Attribution (CC BY) license (http://creativecommons.org/licenses/by/4.0/). 